\title{
Pregnancy Complicated with a Giant Cervical Polyp: Case Report
}

\section{Dev Servikal Poliple Komplike Olan Gebelik}

\section{Ayşe KIRBAŞ, ${ }^{a}$ \\ Ebru Hacer BIBEROĞLU, Halil Korkut DAĞLAR, ${ }^{a}$ \\ Hakan TIMUR, ${ }^{a}$ \\ Dilek UYGUR, ${ }^{a}$ \\ Nuri DANIŞMANa}

${ }^{a}$ Clinic of Perinatology,

Zekai Tahir Burak Women's Health Training and Research Hospital, Ankara

Geliş Tarihi/Received: 30.10 .2014

Kabul Tarihi/Accepted: 16.01.2015

This study was presented as a poster at $13^{\text {th }}$ World Congress in Fetal Medicine, June 29-July 3, 2014, Nice, France.

Yazışma Adresi/Correspondence: Ayşe KIRBAŞ

Zekai Tahir Burak Women's Health Training and Research Hospital, Clinic of Perinatology, Ankara, TÜRKIYE/TURKEY

drayse1982@yahoo.com

\begin{abstract}
Cervical polyp is one of the most common lesions of cervix that occurs in about 2-5\% all of women mostly after the forth decade of life. Cervical polyps are typically diagnosed incidentally during vaginal examination. Their size is often small, with mostly less than 2 centimeters. Giant cervical polyp is an uncommon variant of classical polyps defined by with a size greater than 4 centimeters. Prevalence of cervical polyp in pregnancy is unknown. There are very limited reports available on the presentation, diagnosis and management of cervical polyps in pregnancy. We describe a case of giant cervical polyp in a young primigravida in pregnancy. This pathology is seen rarely. We found only two cases that pregnancy complicated with giant polyp in the literature. It has never been reported as a cause of cervical dilatation in pregnancy.
\end{abstract}

Key Words: Pregnancy; polyps; cervix uteri

ÖZET Serviksin en sık karşılaşılan lezyonlarından biri olan servikal polip, tüm kadınların \%25 'inde görülür. Genellikle 40'li yaşlardan sonra ortaya çıkar ve vajinal muayene esnasında tesadüfen tanı alırlar. Servikal poliplerin boyutları genelde 2 santimetrenin altındadır. Dev polip, polip boyutunun 4 santimetrenin üzerinde olması seklinde tanımlanır ve klasik poliplerin nadir bir şeklidir. Servikal poliplerin gebelikteki sıklı̆̆ı bilinmemektedir. Ayrıca, servikal poliplerin gebelikte başvuru şekli, tanısı ve nasıl yönetildiğine dair literatür bilgisi oldukça sınırlıdır. Biz burada genç bir gebede karşılaştığımız dev bir servikal polip vakasını sunuyoruz. Bu patoloji oldukça nadir görülmektedir. Literatür taramasında dev servikal poliple komplike olan sadece 2 gebelik vakasıyla karşılaştık. Servikal dilatasyona sebep olan servikal polip vakası ise daha önce hiç bildirilmemiştir.

Anahtar Kelimeler: Gebelik; polipler; serviks uteri

Turkiye Klinikleri J Gynecol Obst 2015;25(4):275-7

ervical polyp (CP) is one of the most common lesions of cervix that occurs in about 2-5\% all of women mostly after the forth decade of life. It is defined as overgrowth of columnar epithelium of the cervix and may originate from the endocervical canal or the ectocervix. ${ }^{1}$

Although cervical polyps can cause some symptoms such as bleeding or vaginal discharge, they are typically diagnosed incidentally during vaginal examination. Their size is often small, with mostly less than 2 centimeters (cm). Giant CP is an uncommon variant of classical polyps defined by with a size greater than $4 \mathrm{~cm}^{2,3}$ 
Prevalence of CP in pregnancy is unknown. There are very limited reports available on the presentation, diagnosis and management of endocervical polyps in pregnancy. ${ }^{4-7}$

The best our knowledge, this is the first case in the literatüre that a giant $\mathrm{CP}$ was associated with cervical dilatation in pregnancy.

\section{CASE REPORT}

A 21-year-old primigravid pregnant woman admitted to our emergency department with a complaint of vaginal bleeding and a mass at 22 weeks of gestation. Her past medical history was uneventful. It was learned that she has never had a cervical Pap smear and she was hospitalized due to abortus imminence with vaginal bleeding at $10^{\text {th }}$ weeks of gestation.

On vaginal examination, a large, reddish, fragile polypoid mass was protruding from the vaginal introitus and it was extending beyond the vulva (Figure 1). Sterile speculum examination revealed that well vascularized mass measuring 9x3.5 cm was originating from the anterior lip of the ectocervix and in part from the endocervix.

A detailed abdominal 2D ultrasonography (USG) was performed to verify the presence of the pregnancy and research for associated anomalies. The USG showed a living fetus consistent with 22 weeks of gestation. Cervical length was measured as $23 \mathrm{~mm}$ with $2 \mathrm{~cm}$ dilatation of the internal os.

$2 \%$ prilokaine was infiltrated in to the base of the polyp, and the polyp-base transfixed with sutures thereby obtaining better haemostasis. Subsequently surgical simple polypectomy was performed.

Gross pathologic examination revealed a polypoid, red, mass attached to a pedicle, measuring $9 \mathrm{x}$ $3,5 \times 2,5 \mathrm{~cm}$ (Figure 2). The surface was a smooth and myxoid surface with occasional focal hemorrhage.

Postoperative course was uneventful. The next day, the funnelling of the cervical canal disappeared. The histopathologic findings revealed no evidence of malignancy in the polyp. Microscopic

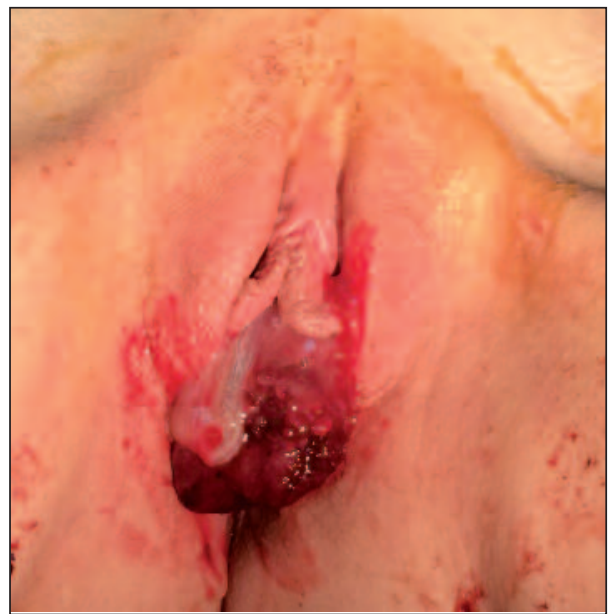

FIGURE 1: Fragile reddish mass was protruding to the vaginal introitus at 22. weeks of gestation.

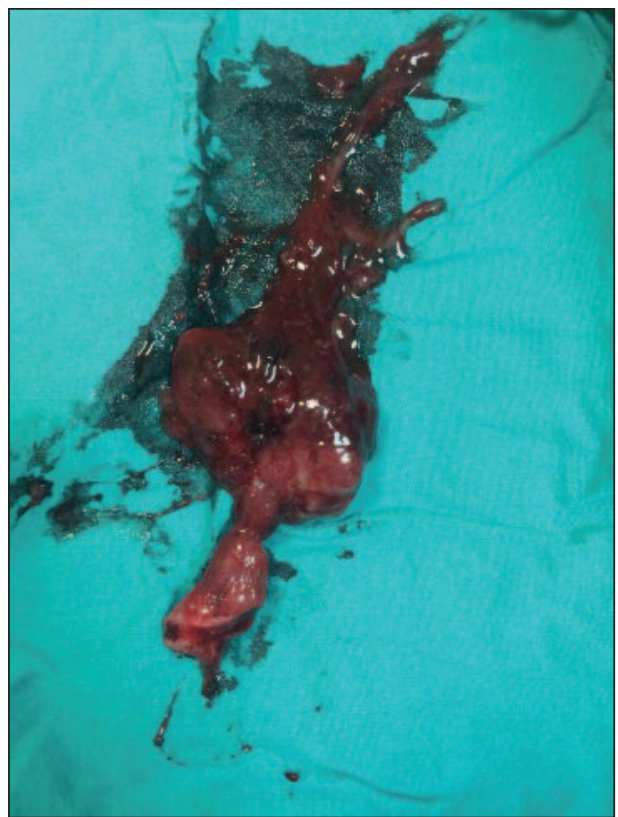

FIGURE 2: Polypectomy material.

examination showed a mass covered by surface epithelium comprised predominately of squamous mucosa with endocervical mucosa with squamous metaplasia.

The pregnancy was carried to term. She was delivered by vaginally at $40^{\text {th }}$ weeks of pregnancy.

We performed the endometrial and cervical canal examination at postpartum $7^{\text {th }}$ weeks by hys- 
teroscopy. Cervix, cervical canal and endometrial cavity were looking normal with no polyp. There was no recurrence within 6 months.

Informed consent was obtained from the patient for publication of this case report and any accompanying images.

\section{DISCUSSION}

We describe a case of giant CP in a young primigravida in pregnancy. This pathology is seen rarely, a literature search reveals no more than 18 cases of giant cervical polyps reported in the last 20 years. ${ }^{2,3}$ We found only two cases that pregnancy complicated with giant polyp in the literature. ${ }^{6,7}$ It has never been reported as a cause of cervical dilatation in pregnancy.

Cervical polyps are associated with various signs, such as vaginal discharge, intermenstrual, postmenopausal or postcoital hemorrhage and/or recurrent vaginal infection and are often incidentally found on pelvic examination. Cervical polyps are also diagnosed during pregnancy; such polyps may involve recurrent bleeding and infection and they can cause of increased risk of bleeding during labor. $^{8}$

The etiology of cervical polyps is unclear. They are mostly benign and associated with multiparity, foreign bodies, chronic cervicitis and ab- normal response of the estrogen. ${ }^{8}$ The factors that why is a polyp becoming symptomatic has not been clarified. It may be that over the course of time, the polyp either becomes infected or outgrow. ${ }^{2-4,9}$

Giant polyps must be differentiated from other lesion of the cervix such as malignancies including sarcoma botryoides, endocervical carcinoma and other benign lesions such as prolapsing fibroids and retained products of conception. ${ }^{10}$

Although cervical polyps are not rare, there are no guidelines for the management of polyps during pregnancy. In this case, the cause of cervical dilatation is not clear but it may due to the weight of the giant polyp itself, the downward distension or only space occupying effect of the polyp. Overgrowth of the polyp may an unusual sample of an exaggerated response of the cervical stroma to high estrogen levels due to pregnancy. It has been noted that the dilatation of cervical os disappeared after removal of the polyp and the pregnancy was carried to term.

In conclusion, we herein demonstrated a giant polyp that is associated with cervical dilatation and disappeared after polypectomy. Despite the benign nature of the cervical polyps during pregnancy, attentive examination is obligatory to exclude malignancy and appropriate counseling must be given to the pregnant.

\section{REFERENCES}

1. Tirlapur SA, Adeyemo A, O'Gorman N, SeloOjeme D. Clinico-pathological study of cervical polyps. Arch Gynecol Obstet 2010;282(5): 535-8.

2. Bucella D, Frédéric B, Noël JC. Giant cervical polyp: a case report and review of a rare entity. Arch Gynecol Obstet 2008;278(3):2958.

3. Grigore M. Giant cervical polyps: Three cases with different pathologies. J Obstet Gynaecol 2014;1-2. 2014 Oct 3:1-2. [Epub ahead of print]
4. Tang $\mathrm{H}$, Jones $\mathrm{I}$. An intrapartum giant cervical polyp. N Z Med J 2004;117(1206):U1181.

5. Adinma Jl. Cervical polyp presenting as inevitable abortion. Trop Doct 1989;19(4):181

6. Panayotidis C, Cilly L. Cervical polypectomy during pregnancy: the gynaecological perspective. J Genit Syst Disor 2013;1(2):2.

7. Robertson M, Scott P, Ellwood DA, Low S. Endocervical polyp in pregnancy: gray scale and color Doppler images and essential considerations in pregnancy. Ultrasound Obstet Gynecol 2005;26(5):583-4.
8. Panayotidis C, Alhuwalia A. Cervical polypectomy during pregnancy: is there any management advances on the last decades? Int J Gynaecol Obstet 2005; 5(1): 1-4.

9. Aridogan N, Cetin MT, Kadayifci O, Atay $\mathrm{Y}$, Bisak U. Giant cervical polyp due to a foreign body in a 'virgin'. Aust N Z J Obstet Gynaecol 1988;28(2):146-7.

10. MacKenzie IZ, Naish C, Rees CM, Manek S. Why remove all cervical polyps and examine them histologically? BJOG 2009;116(8):11279. 